Polónyi Istuán

Debreceni Egyetem BTK Neveléstudományi Intézet

\title{
Harmadik csapás
}

\section{A felsöoktatási felvételi ingadozásai - avagy az oktatáspolitika társadalomismeretének hiánya}

Ebben az irásban a hazai felsóoktatási felvételi tendenciáit és annak néhány összefüggését igyekszünk bemutatni, nem függetlenül a 2020. évi felvételi - sokak által meglepónek vélt alakulásától. Az irás alcimét egyik kolléganómtól plagizáltam, aki, amikor megmutattam neki a 2020-as felvételi számokat, és annak okairól beszélgettünk, kijelentette, hogy az alapvetố ok a felsốoktatás-politika társadalomismeretének hiánya. A fócím pedig arra utal, hogy a hazai felsóoktatás az elmúlt alig több mint tíz évben harmadszor szenved el olyan oktatáspolitikai ráhatást, ami súlyos helyzetbe sodorja.

\section{A 2020-as felvételi}

2 014-ben - 2020. január 1-jei hatályba léptetéssel - a Kormány 335/2014. (XII. 18.) Korm. rendelete (a felsőoktatási felvételi eljárásról szóló 423/2012. [XII. 29.] Korm. rendelet módosításáról) 10 § (2) bekezdésében radikálisan módosította a felvételi feltételeinek szabályait. Eszerint ,alapképzésre, osztatlan képzésre [...] az a jelentkező vehető fel, aki a) legalább B2 szintü, általános nyelvi, komplex nyelvvizsgával, vagy azzal egyenértékü okirattal rendelkezik és b) legalább egy emelt szintü érettségi vizsgát tett vagy felsőfokú végzettséget tanúsító oklevéllel rendelkezik." (A b) pontot nem kell alkalmazni a müvészet képzési terület képzésére jelentkezőre.)

Majd 2019 novemberében a 2019. (XI. 14.) Korm. rendelet (a felsőoktatási felvételi eljárással összefüggésben egyes kormányrendeletek módosításáról) 5. § szerint „nem lép hatályba a 335/2014. (XII. 18.) Korm. rendelet 10. § (2) bekezdése.” Tehát az utolsó pillanatban eltörölték a kötelező nyelvvizsga követelményét, de az emelt szintű érettségi általánosan kötelező elöírását megtartották. Köztudott, hogy a szeptemberben induló, ún. általános felvételi eljárásra való jelentkezés december második felében szokott indulni, és február közepén zárul. A módosítás tehát látszólag éppen időben történt, hiszen egy hónappal a jelentkezések kezdete előtt jelent meg. A felvételi szabályok változtatgatásának következménye azonban mégis rendkívül jelentős volt (1. táblázat). 


\begin{tabular}{|c|c|c|c|c|}
\hline \multicolumn{5}{|c|}{ 1. táblázat. A jelentkezök és felvettek létszámának alakulása } \\
\hline $\begin{array}{l}\text { A szeptemberben } \\
\text { induló képzésekre } \\
\text { irányuló felvételiken }\end{array}$ & $\begin{array}{c}\text { Összes } \\
\text { jelentkező }\end{array}$ & $\begin{array}{c}\text { Az adott évben } 19 \text { és } \\
18 \text { vagy kevesebb éves } \\
\text { jelentkező együtt }\end{array}$ & $\begin{array}{l}\text { Összes } \\
\text { felvett }\end{array}$ & $\begin{array}{l}\text { Az adott évben } 19 \text { és } \\
18 \text { vagy kevesebb éves } \\
\text { felvett együtt }\end{array}$ \\
\hline 2015 & 105646 & 36606 & 72260 & 25688 \\
\hline 2016 & 111219 & 36312 & 74901 & 25794 \\
\hline 2017 & 105868 & 34388 & 72758 & 25429 \\
\hline 2018 & 107700 & 35785 & 75291 & 26483 \\
\hline 2019 & 112033 & 39252 & 78980 & 29053 \\
\hline 2020 & 91460 & 32083 & 68112 & 26961 \\
\hline $2019-2020^{1}$ & 20573 & 7169 & 10868 & 2092 \\
\hline $2020 / 2019(\%)$ & $82 \%$ & $82 \%$ & $86 \%$ & $93 \%$ \\
\hline
\end{tabular}

Forrás: felvi.hu adatbázis

${ }^{1}$ 2019. évi adat mínusz 2020. évi adatok

2020-ban a jelentkezők száma mintegy 20,5 ezerrel csökkent, és ilyen kevesen még nem jelentkeztek, amióta központi felvételi rendszer van. A jelentkezettek közül kicsit több mint 7 ezret tesz ki a 18 éves vagy fiatalabb és a 19 éves korosztály együttes létszámának csökkenése - ők azok, akik nagyrészt a felvételi évében érettségiznek. Ehhez tegyük hozzá rögtön, hogy a folyamatokban a demográfia nem játszhatott szerepet, mivel a 17 éves népesség létszáma 2020-ban kb. 97200 fö, 2019-ben 97 800, 2018-ban 97500 - tehát a korosztályi létszám jelentéktelen mértékben ingadozik, a jelenséget nem magyarázza. A felvett létszámon már tompítottabban jelentkezik a folyamat - a felvételi rendszer sajátosságai miatt, amelynek nyomán az intézményi kapacitásokat igyekeznek feltölteni a „vonalhúzás” során -, de a 2020. évi általános eljárásban felvettek számára is igaz, amit a jelentkezőkre írtunk, hogy ilyen kevés hallgatót még nem vettek fel, amióta központi felvételi rendszer van. Az összes felvett létszám mintegy 10 ezerrel csökkent, azon belül a 19 éves és fiatalabbak száma mintegy 2,1 ezerrel. Ezek az adatok is érzékeltetik, hogy az oktatáspolitikai csapás az elmúlt tizenöt év legnagyobb felsőoktatási szükítését eredményezte. Tegyük hozzá, hogy tudatosan, hiszen a kormányrendeletek „a minőség jegyében” több mint öt éve megszülettek.

Azt is azonnal észre lehet venni, hogy a létszámszükítés elszenvedői nagyobbrészt a részidős első diplomaszerzésre jelentkezők voltak (2. táblázat). 
Polónyi István: Harmadik csapás

2. táblázat. Az alap és osztatlan képzésre összesen és a részidős képzésre jelentkezők és felvettek száma

\begin{tabular}{|c|c|c|c|c|c|c|}
\hline & $\begin{array}{c}\text { AO } \\
\text { jelentkező }\end{array}$ & $\begin{array}{c}\text { AO } \\
\text { felvett }\end{array}$ & $\begin{array}{c}\text { AON } \\
\text { jelentkezo }\end{array}$ & $\begin{array}{c}\text { AON } \\
\text { felvett }\end{array}$ & $\begin{array}{c}\text { AOR } \\
\text { jelentkezo }\end{array}$ & $\begin{array}{c}\text { AOR } \\
\text { felvett }\end{array}$ \\
\hline 2015 & 78607 & 51670 & 64120 & 40145 & 14487 & 11525 \\
\hline 2016 & 83271 & 53999 & 65727 & 41021 & 17544 & 12978 \\
\hline 2017 & 82703 & 55225 & 63624 & 41318 & 19079 & 13907 \\
\hline 2018 & 84291 & 57068 & 64708 & 42320 & 19583 & 14748 \\
\hline 2019 & 88839 & 61041 & 68459 & 44989 & 20380 & 16052 \\
\hline 2020 & 69281 & 49640 & 56691 & 39741 & 12590 & 9899 \\
\hline & & & & & & \\
\hline $2019-2020^{2}$ & 19558 & 11401 & 11768 & 5248 & 7790 & 6153 \\
\hline $2020 / 2019 \%$ & $78 \%$ & $81 \%$ & $83 \%$ & $88 \%$ & $62 \%$ & $62 \%$ \\
\hline
\end{tabular}

Forrás: felvi.hu adatbázis

AO - alap és osztatlan képzés

AON - alap és osztatlan képzés nappali munkarendben

AOR - alap és osztatlan képzés részidős munkarendben

${ }^{2} 2019$. évi adat mínusz 2020. évi adatok

Az első diplomaszerzésre irányuló jelentkezéseket, azaz az alap- és osztatlan képzésre első helyen jelentkezők (valamennyi tagozaton) számát vizsgálva a csökkenés kicsit több mint 19,5 ezer fö, azaz ezer fö híján a teljes csökkenés az első diplomára irányuló képzéseknél volt (a mester- és FSZ képzés esetében alig volt visszaesés). Szembetünő, hogy miközben a nappali alap- és osztatlan képzésre felvettek száma 12\%-kal csökkent, addig a részidős képzésre felvetteké több mint harmadával.

Elég nyilvánvaló, hogy nemcsak - sőt nem elsősorban - a nyelvvizsga körüli hercehurca riasztott vissza, hanem az emelt szintü érettségi, amelynek a hatása jelentősebb volt. A részidős képzésre jelentkezők esetében egészen biztos, hiszen többüknek le kellene azt tenni - újra érettségizve. Hozzá kell tenni azt is, hogy ez is nyilvánvaló célja volt a minőségelvet túlhangsúlyozó felsőoktatás-politikának.

Érdemes egy pillantás erejéig a szakcsoportok szerinti csökkenést is megvizsgálni (3. táblázat). Szembetünő a pedagógus, a müszaki, az informatikai, az agrár és a sporttudományi képzésekre jelentkezők számának radikális (20\%-ot meghaladó) csökkenése. Ez már nem biztos, hogy célja volt a felsőoktatás-politikának - inkább tudatosságának hiányosságaira mutatnak rá. Hogy miért pont ezeken a képzéseken csökkent a jelentkezők száma legradikálisabban, arra a 4. táblázatból kapunk magyarázatot 
3. táblázat. A jelentkezések csökkenésének képzési szerkezete

\begin{tabular}{|l|c|c|c|c|}
\hline & \multicolumn{2}{|c|}{$\left(\mathbf{2 0 2 0 - 2 0 1 9 ) / 2 0 1 9}(\%)^{\mathbf{3}}\right.$} & \multicolumn{2}{c|}{$(\mathbf{2 0 2 0 - 2 0 1 9 ) / 2 0 1 9 ( \% )}$} \\
\hline & Jelentkezők & AON Jelentkezők & Felvett & AON felvett \\
\hline agrár & $-25 \%$ & $-31 \%$ & $-23 \%$ & $-38 \%$ \\
\hline államtudományi & $-11 \%$ & $-28 \%$ & $3 \%$ & $-37 \%$ \\
\hline bölcsészettudomány & $2 \%$ & $8 \%$ & $4 \%$ & $-33 \%$ \\
\hline gazdaságtudományok & $-16 \%$ & $-10 \%$ & $-13 \%$ & $-19 \%$ \\
\hline informatika & $-20 \%$ & $-23 \%$ & $-14 \%$ & $-24 \%$ \\
\hline jogi & $1 \%$ & $18 \%$ & $-2 \%$ & $23 \%$ \\
\hline müszaki & $-34 \%$ & $-34 \%$ & $-34 \%$ & $-29 \%$ \\
\hline múvészet & $-6 \%$ & $-14 \%$ & $8 \%$ & $-31 \%$ \\
\hline müvészetközvetítés & $7 \%$ & $10 \%$ & $-8 \%$ & $12 \%$ \\
\hline orvos- és egészségtudomány & $-16 \%$ & $-17 \%$ & $-7 \%$ & $-27 \%$ \\
\hline pedagógusképzés & $-40 \%$ & $-33 \%$ & $-29 \%$ & $-48 \%$ \\
\hline sporttudomány & $-24 \%$ & $-19 \%$ & $-8 \%$ & $-37 \%$ \\
\hline társadalomtudomány & $-5 \%$ & $6 \%$ & $5 \%$ & $-8 \%$ \\
\hline természettudomány & $-11 \%$ & $-13 \%$ & $-10 \%$ & $-27 \%$ \\
\hline
\end{tabular}

Forrás: felvi.hu adatbázis alapján saját számítás

${ }^{3}$ 2020. és 2019. évi adat különbsége a 2019. évi bázishoz viszonyítva, százalékban kifejezve

4. táblázat. Az alap-és osztatlan képzési területekre az adott évben felvettek között a nyelvvizsgáért és az emelt szintü érettségiért többletpontszámot kapottak aránya

\begin{tabular}{|c|c|c|c|c|}
\hline & \multicolumn{2}{|c|}{ Nyelvvizsgáért } & \multicolumn{2}{|c|}{ Emeltszintü érettségiért } \\
\hline & 2015. & 2018. & 2015 & 2018. \\
\hline \multicolumn{5}{|c|}{ Alapképzésre felvettek } \\
\hline agrár & $51 \%$ & $45 \%$ & $31 \%$ & $27 \%$ \\
\hline bölcsészettudomány & $49 \%$ & $47 \%$ & $93 \%$ & $92 \%$ \\
\hline gazdaságtudomány & $55 \%$ & $56 \%$ & $45 \%$ & $48 \%$ \\
\hline informatika & $71 \%$ & $74 \%$ & $43 \%$ & $41 \%$ \\
\hline jogi & $43 \%$ & $46 \%$ & $18 \%$ & $22 \%$ \\
\hline közigazgatási/államtudományi & $63 \%$ & $76 \%$ & $51 \%$ & $50 \%$ \\
\hline müszaki & $64 \%$ & $66 \%$ & $39 \%$ & $37 \%$ \\
\hline \multicolumn{5}{|l|}{ müvészeti } \\
\hline \multicolumn{5}{|l|}{ müvészetközvetítési } \\
\hline orvos- és egészségtudományi & $57 \%$ & $51 \%$ & $39 \%$ & $45 \%$ \\
\hline pedagógusképzés & $47 \%$ & $46 \%$ & $20 \%$ & $18 \%$ \\
\hline sporttudomány & $42 \%$ & $30 \%$ & $55 \%$ & $34 \%$ \\
\hline társadalomtudomány & $41 \%$ & $39 \%$ & $94 \%$ & $93 \%$ \\
\hline természettudomány & $66 \%$ & $69 \%$ & $61 \%$ & $68 \%$ \\
\hline
\end{tabular}


Polónyi István: Harmadik csapás

\begin{tabular}{|l|c|c|c|c|}
\hline & \multicolumn{2}{|c|}{ Nyelvvizsgáért } & Emeltszintủ érettségiért \\
\hline & $\mathbf{2 0 1 5}$ & $\mathbf{2 0 1 8}$ & $\mathbf{2 0 1 5}$ & $\mathbf{2 0 1 8 .}$ \\
\hline \multicolumn{5}{|c|}{ Osztatlan képzésre felvettek } \\
\hline agrár & $77 \%$ & $61 \%$ & $97 \%$ & $72 \%$ \\
\hline jogi & $63 \%$ & $63 \%$ & $71 \%$ & $69 \%$ \\
\hline müszaki & $91 \%$ & $68 \%$ & $100 \%$ & $100 \%$ \\
\hline orvos & $84 \%$ & $80 \%$ & $99 \%$ & $99 \%$ \\
\hline pedagógus & $36 \%$ & $37 \%$ & $81 \%$ & $84 \%$ \\
\hline államtudományi & & $97 \%$ & & $82 \%$ \\
\hline gazdasági & & $72 \%$ & & $100 \%$ \\
\hline
\end{tabular}

Forrás: 2015. és 2018. évi felvételi adatbázisok alapján saját számítás

Elég világosan látszik, hogy 2018-ban az agrár, az informatikai, a műszaki, a pedagógus és a sporttudományi képzések esetében az emelt szintü érettségivel rendelkezők aránya $45 \%$ alatt volt, s ez valószínüleg nem sokat változott 2020-ra, ami riasztóan hathatott a jelentkezőkre (hasonló felkészültséget feltételezve). ${ }^{1}$

Ha a 2020. évi jelentkezések változása és a 2018-as felvettek nyelvvizsga-aránya, valamint a 2020-as jelentkezések változása és a 2018-ban felvettek emelt szintü érettségi aránya közötti korrelációt megvizsgáljuk a szakcsoportok halmazán, azt találjuk, hogy az összes jelentkezők számának változása az emelt szintü érettségivel mozog együtt viszonylag erös $(+0,6157)$ korrelációval (a nyelvvizsga-aránnyal a korreláció $+0,2728)$. Ugyanezt a felvettek arányának változása és az emelt szintủ érettségizettek aránya között vizsgálva még erőteljesebb együttmozgást tapasztalunk (+0,7061) (Melléklet 3. táblázat). Az AON képzési szintre jelentkezők száma viszont mindkét jellemzővel együttmozog egy nem túl erős $(+0,3,+0,4$ körüli) korrelációval. Ebből arra lehet következtetni, hogy a részidős képzésre jelentkezőket erősen eltántorította az emelt szintü érettségi, a nappali tagozatos alap- és osztatlan képzésre jelentkezőket pedig kisebb erővel ugyan, de mindkét új követelmény.

Fontos megjegyezni, hogy a jelentkezők szakeloszlása és „hozott pontszáma” mögött erőteljes szocio-ökönómiai sajátosságok állnak. A tanulók társadalmi, gazdasági helyzetének lakóhely szerinti differenciáltsága, ami együtt jár az iskolarendszer differenciáltságával, alapvetően meghatározza azt, hogy mely felsőoktatási intézmények szenvedik meg leginkább a jelentkezők számának csökkenését, mivel a felsőoktatási intézmények rekrutációja mind területileg, mind társadalmilag erősen meghatározott (ld. erről Polónyi, 2012, 2018, 2019).

A jelentkezők létszámcsökkenése alig érintette az ELTE mellett a művészeti egyetemeket (kivéve a Színház- és Filmmüvészetit), az Állatorvostudományit és három nem állami egyetemet, a Pázmányt, a Milton Friedmant és az Andrássyt. A jelentkezési létszámcsökkenés volumenét illetően a legnagyobb vesztesek a vidéki egyetemek: a Debreceni Egyetem, a Széchenyi és a Szent István egyetemek. De ott vannak a nagy vesztesek között a fővárosi gazdaságtudományi és müszaki egyetemek is.

A felvettek némileg más tendenciákat mutatnak - a különbségek az intézményi profiloktól és az egyes szakok államilag finanszírozott minimum pontszámhatáraitól és természetesen az adott intézménybe jelentkezők pontszámaitól függenek. Az intézmények között csak a 100 fónél nagyobb létszámot felvett intézményeket tekintve - a legnagyobb nyertes két művészeti egyetem: a MOME és a Táncművészeti, az előzőnek $6 \%$-kal, az utóbbinak $12 \%$-kal növekedett a felvett létszáma az előző évi általános eljáráshoz viszonyítva. 3\% körül növekedett a felvett létszám a Nemzeti Közszolgálati Egyetem, a Testnevelési 
Egyetem és a Liszt Ferenc Zeneművészeti Egyetem esetében, és 2\% körül a Milton Friedman Egyetemen, az Állatorvostudományi Egyetemen és a Képzőművészeti Egyetemen. A tavalyival azonos a felvett létszám a Pázmányon, az összes többi intézmény esetében pedig kevesebb mint az előző évben. A fóvárosi nagy egyetemek 1-4\%-ot veszítettek (SE 1\%-ot, ELTE 2,6\%-ot, BME 3,1\%-ot), kivéve a Károlit, amelyik 6,6\%-ot és a Corvinust, amelyik 19,5\%-ot, továbbá az Óbudait, amelyiket 28,9\% és a Színház- és Filmmüvészetit, amelyet 36,9\% veszteség ért. A vidéki egyetemek ennél nagyobb veszteséget szenvedtek. Legkevesebbet az SZTE: 4\%-ot, a PTE pedig 6,5\%-ot vesztett. A Debreceni Egyetem 14,4\%-ot, a ME 18,1\%-ot, a Soproni Egyetem 24,1\%-ot, a Pannon Egyetem 25,4\%-ot, a Széchenyi 31,1\%-ot, a Szent István 35,5\%-ot és a Kaposvári 36,2\%-ot. Az alkalmazott tudományegyetemek esetében is azt látjuk, hogy a fővárosi intézmények nagyjából a fővárosi egyetemhez hasonló eredményt értek el, viszont a vidéki alkalmazott tudományegyetemek felvett létszáma a tavalyinak mindössze kétharmada.

Az adatokra tekintve két dolog látszik elég egyértelmüen.

Részint az, hogy a felsőoktatás-politikai lépés vesztesei a vidéki intézmények - ami azt mutatja, hogy a vidéki alsó középosztály gyermekei szorultak ki a döntés nyomán, ami nem csoda, hiszen ezek a fiatalok járnak nem túl erős vidéki középiskolákba, ahol nehezebb emelt szintü érettségit tenni, s a szülők sem tudnak sokat áldozni különórákra.

A vidéki egyetemek több mint 10\%-ponttal, a vidéki alkalmazott tudományok egyetemei több mint harmadnyival tudtak kevesebb fiatalt felvenni (5. táblázat).

5. táblázat. A felvettek számának alakulása 2019-hez viszonyitva intézménycsoportonként

\begin{tabular}{|l|c|c|}
\hline & Fővárosi & Vidéki \\
\hline Egyetem & $93 \%$ & $83 \%$ \\
\hline Alkalmazott tudományok egyeteme & $93 \%$ & $65 \%$ \\
\hline Főiskola & $57 \%$ & $60 \%$ \\
\hline
\end{tabular}

Forrás: felvi.hu adatai alapján saját számítás

A másik, ami látszik, hogy az átalakulásba vont intézmények közül a MOME és az Állatorvostudományi tudott a tavalyinál több hallgatót felvenni (a MOME 6\%-kal, az ATE 2\%-kal), a többi viszont katasztrofálisan szerepelt. A Corvinus és a Miskolci Egyetem közel 20\%-ot veszített, a Soproni Egyetem 24\%-ot, a Széchenyi 31\%-ot, a Szent István, a Kaposvári, valamint a Színház- és Filmmüvészeti Egyetem valamivel több mint harmadát, a Neumann a felét vesztette el a tavalyi létszámnak. Kérdés, hogy a sikertelenség ösztönözte-e az átalakítást, vagy az átalakítás okozta a hallgatóveszteséget. A két szakmai lobbi által motivált privatizáció (MOME, ATE) sikeres, de a Corvinus szereplése inkább az utóbbira enged következtetni.

\section{A jelentkezések és a felvételek hosszabb távú alakulása}

A 2020. évi jelentkezések ilyen mértékü visszaesése nem példa nélküli a hazai felsőoktatás elmúlt tizenöt évében. 2008-ban és 2013-ban hasonló - bár a 2020-asnál valamivel magasabb szintről történt - visszaesést láthatunk.

Ha az ezredforduló utáni felvételi jelentkezéseket vizsgáljuk (1. ábra), akkor azt látjuk, 2007-2008-ban, illetve 2013-ban alakultak ki mélypontok - akár 40-50 ezer fös csökkenéseket is regisztrált a Felvi adatbázis. Míg azonban 2009 után a számok újra növekedni kezdtek, 2013 után egyfajta stagnálás figyelhető meg az adatokban, amelyek így egy alacsonyabb szinten látszott stabilizálódni, és erre az alacsony szintre következett 
be a fentebb említett 2020-es jelentkezési létszámcsökkenés

$\mathrm{Az}$ ingadozás mögött nyilvánvalóan nem demográfiai folyamatok állnak, mert jóllehet a 2000-es évek elején a fiatal korosztályok létszáma csökkenésének vagyunk tanúi, azonban ez a csökkenés nem hektikus. Az ábrában a 18-22 éves korosztály alakulását pontsor illusztrálja. A jelentkezők számának trendje és a korosztályi trend között van ugyan együttmozgás, azonban a jelentkezők számában jól láthatóak az oktatáspolitikai hatások az egyes szakadékoknál. Azt is érdemes szem előtt tartani, hogy a felsőoktatás (nappali tagozatos) jelentkezőinek tényleges merítési bázisát adó érettségizettek létszáma a korosztályi létszámhoz viszonyítva még lassabban csökkent - mivel az érettségizett arány növekedett (2. ábra). (Sajnos nem áll rendelkezésre a 2020-as érettségi statisztika, pedig a „pandémiás érettségi” nyilvánvalóan befolyásolta a felvételit - különösen az idősebb, részidős képzésre jelentkezők esetében.)

Végül is a felvételi létszámingadozásokat nem a demográfia okozta, hanem az oktatáspolitikai vitustánc. Az oktatáspolitika társadalomismeretének hiánya. Úgy tünik, hogy a felsőoktatásba jelentkezőknek mintegy 20-25\%-a az elengedhetetlen költségviselés határán vállalkozik a továbbtanulásra, $\mathrm{s}$ visszariad, ha a feltételek változása megnöveli a szükséges erőfeszítések nagyságát. S alighanem ez az alsóbb rétegeket jelenti.

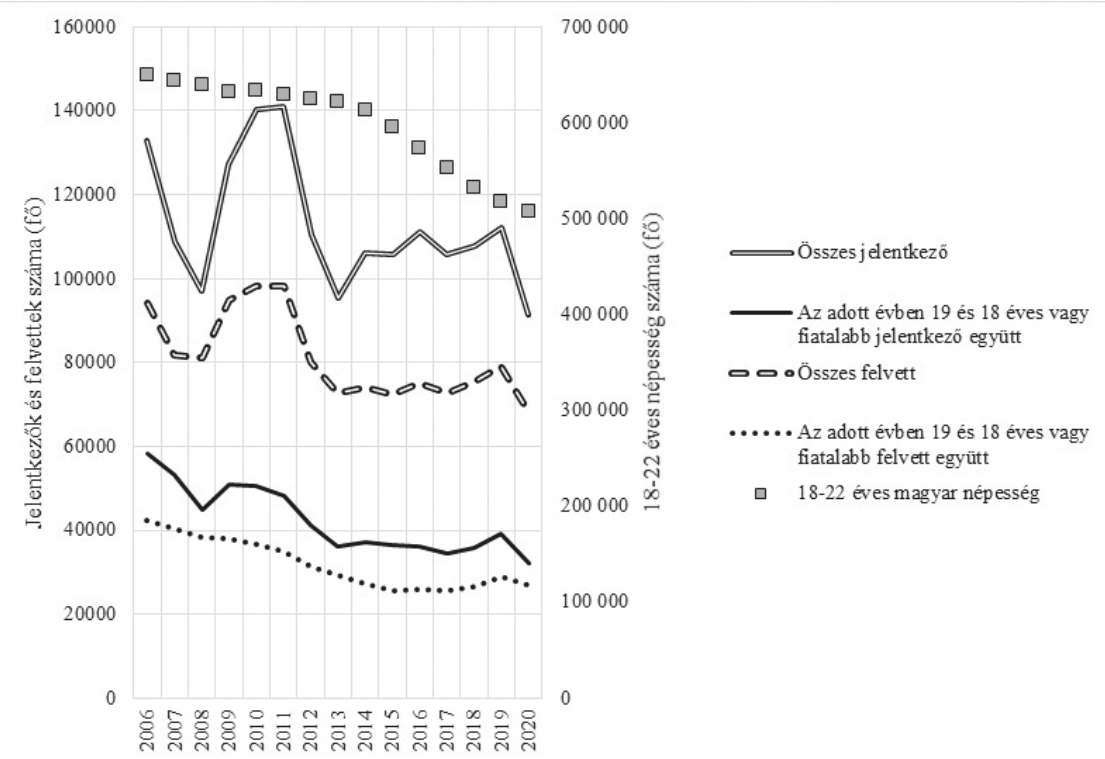

1. ábra. A szeptemberi kezdésü programokra (azaz ún. Általános eljárás keretében) történö felsőoktatási jelentkezések számának alakulása, 2001-2020 Forrás: Felvi.hu adatai alapján saját szerkesztés 


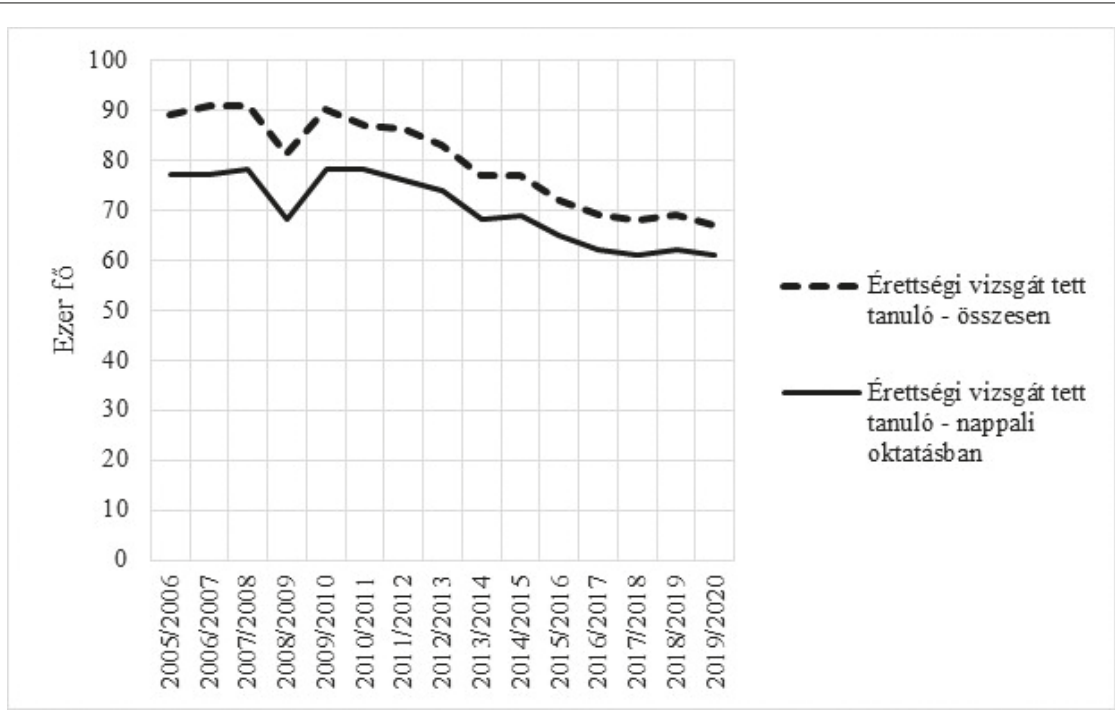

2. ábra. Az érettségit tett létszám az adott évben

Forrás: KSH adatai alapján saját szerkesztés

Azaz az ingadozások mögött az oktatáspolitika „,csapásai” állnak.

Az első csökkenés mögött egy tandíj-bevezetési kísérlet állt. 2006-ban a felsőoktatási költségmegosztás kapcsán felmerült első elképzelések a diploma megszerzését követő, utólagos képzési hozzájárulásról szóltak, majd fejlesztési részhozzájárulás (FER) elnevezéssel merült fel a tandíj bevezetése. Végül is képzési hozzájárulás elnevezéssel kerül be a 2006-os baloldali kormányváltást követő államháztartási reform kapcsán a felsőoktatási törvénybe. ${ }^{2} \mathrm{~A}$ felsőoktatási törvény szerint az államilag támogatott és költségtérítéses képzésről szóló szabályozás azzal egészült ki, hogy az államilag támogatott hallgató képzési hozzájárulás fizetésére köteles. A törvény külön szakaszban szabályozta a képzési hozzájárulást. Ennek nyomán a képzési hozzájárulás összege 2008 szeptemberétől az alapképzésben 105 ezer, a mesterképzésben 150 ezer forint lett volna évente, amely összegtől az intézmények plusz-mínusz ötven százalékkal eltérhettek, de a legjobb 15\% tandíjmentességben részesült volna.

Az ellenzék azonban a képzési hozzájárulás szakpolitikai problémáját nagypolitikai szintre vitte. Így a Fidesz és a KDNP népszavazási kezdeményezése és aláirásgyüjtése nyomán - és az OVB és az Alkotmánybíróság nem jelentéktelen értelmezési vitája után - a képzési hozzájárulás megszüntetése 2008. március 9-én a vizitdíjjal és a kórházi napidíjjal együtt népszavazásra került. A népszavazáson a képzési hozzájárulás eltörlése (is) megkapta a szükséges szavazatokat.

A tandíj tehát nem lett bevezetve, ennek ellenére a tandíj bevezetésének híre rendkívül jelentős csökkenést eredményezett a jelentkezők (s ennek nyomán a felvettek számában) - ez áll a 2007-2008-as jelentkezési visszaesés mögött.

A második csökkenés is a felsőoktatási költségmegosztással kapcsolatos hír hatása. A tandíjat ugyan elvetették, de a költségtérítéses rendszer, amelyet 1996-ban vezettek be (amelynek nyomán a mai napig a hallgatók egy része államilag támogatott vagy „ösztöndíjas", s nem fizet tandíjat, a másik része pedig költségtérítéses, illetve önköltséges, azaz a teljes képzési költségét kifizeti tandíjként), ${ }^{3}$ mindvégig érintetlenül megmaradt. Olyannyira, hogy a 2010-ben hatalomra kerülő konzervatív kormány - a miniszterelnök 2012 őszi elhíresült beszédében hangsúlyozott, bevezetni tervezett „önfenntartó 
felsőoktatás" keretében - az államilag finanszírozott létszámot radikálisan le akarta szükíteni, s a hallgatók többségével a teljes képzési költséget ki akarta fizettetni (mely önköltségfizetést a diákhitel 2 konstrukcióval könnyítették volna, amely hitelt a munkába állás után kellett volna visszafizetni). A hallgatói megmozdulások után ettől a kormány részben ${ }^{4}$ visszalépett, azonban a bejelentés hatására ezúttal is jelentős jelentkezési létszámcsökkenés következett be. Ez áll a 2013. évi jelentkezések visszaesése mögött.

Ráadásul a felsőoktatás szűkítése és a létszámcsökkenés csak igen kis mértékben „,múlt el” a napjainkig tartó időszakban. Részint a Széll Kálmán Terv 2.0 keretében 2011ben és 2012-ben a kormány közel 100 milliárd forintot vont ki a szféra állami támogatásából, részint a konzervatív felsőoktatás-politika a minőség és a világhírü felsőoktatási rendszer elérésének ${ }^{5}$ jelszava mögött valójában a felsőoktatás beszükítésére törekedett, ami számos dokumentumból kitünik. ${ }^{6}$

Ennek nyomán 2013 óta a felvett létszám csak igen szerény mértékben növekedett. A létszámvisszafogás alapvető eszköze a kormányzati képzési struktúra és a finanszírozott létszám szabályozása. Ennek keretében ${ }^{7}$ 2013-ban 10 alap- és 2 osztatlan képzésnek megszüntették az állami támogatását, ${ }^{8}$ majd 2014-ben ugyanennek a 12 szaknak az állami finanszírozott helyeire való bekerülését rendkívül magas pontszámokhoz kötötték, majd 2015-ben 32 alap és 9 osztatlan szak került ebbe a kategóriába, ma pedig 30 alap és 10 osztatlan szak van ebben a csoportban. A szabályozás eredményeként 2013-ról 2019-re az általános felvételi eljárásban felvett létszám 73 ezerről mindössze 79 ezerre növekedett (miközben 2010-ben több mint 98 ezer volt) (ld. Melléklet 1. és 2. táblázat).

És ebben a helyzetben lépett életbe a harmadik oktatáspolitikai csapás, a kötelező emelt szintü érettségi, amelynek hatását korábban elemeztük.

\section{Befejezésül}

A felsőoktatás 2020. évi általános (a szeptemberben induló képzésekre történő, azaz a fö) felvételi eljárása látszólag nagy meglepetést hozott a jelentkezők és ennek nyomán a felvettek számának radikális csökkenésével. Sajátos kormányzati reagálásként lehetett hallani, hogy ezzel javult a bejutás esélye, mert 74\%-ot felvettek. Ez az indoklás nyilvánvalóan propagandisztikus - vagy a folyamatok ismeretének teljes hiányát bizonyítja -, mivel a felvételi eljárás sajátosságai miatt a kevesebb jelentkezőből mindig többet vesznek fel, így a korábbi 2013-as csökkenésnél 76\%, a 2008-as csökkenésnél 84\% volt a bejutási arány.

A jelentkezők és a felvettek számának ez a radikális csökkenése nem elöször fordult elö a hazai felsőoktatás közelmúltjában.

A 2008-as visszaesés a tandíjbevezetés szándékának hatására következett be. A 2013as hanyatlás mögött is a felsőoktatási költségmegosztás radikális módosításának, az államilag finanszírozott hallgatólétszámnak a tervezett csökkentése állt.

A 2020-as visszaesés esetében pedig egyértelmü, hogy a konzervatív kormány tudatos felsőoktatás-politikájának hatásáról van szó. A 2014-ben hozott felvételi követelményre vonatkozó előírás - a felvételhez kötelezővé tett emelt szintủ érettségi - hatása érett be.

A konzervatív kormány gazdaság- és oktatáspolitikája, amely az oktatási rendszernek a rövid távú gazdasági igényekhez történő igazítását szorgalmazza, növekvő arányú diplomás munkaerő helyett szakmunkásokat, kétkezi munkásokat igényel. Ezt igazolja az is, hogy az EU 2020 stratégia célkitüzései között szereplö, 2020-ban elérendő 40\%os ajánlott fiatal diplomás arányra nem vállalkozott a magyar kormány. Ennek nyomán 2018-ban mindössze 30,8\% volt ez az arány, amivel az OECD országok között az utolsók között vagyunk, csak négy országban kevesebb, mint nálunk. ${ }^{9}$ (Miközben az e tekintetben vezető országokban közel kétszer akkora, mint a magyar: Litvániában 55,6\%, 
Írországban 56,2\%, Japánban 60,7\%, Kanadában $61,8 \%$, Koreában $69,6 \%$.)

A minőségelv és a világszínvonal elérésének megmosolyogtató törekvéseivel (ld. erről Polónyi és Kozma, 2019) indokolt felsőoktatás-szükítés súlyos társadalmi következményekkel jár. A hazai közoktatás erősen szelektív jellege különösen felerösíti azt a hatást, amely a létszámszúkítés miatt egyébként is fenyeget: nevezetesen azt, hogy a felsőoktatásból kiszorulnak az alsóbb társadalmi rétegek.

És persze súlyos következményei lesznek a hosszú távú gazdasági fejlődésben is (Polónyi 2020).

A minôségelv és a világszinvonal elérésének megmosolyogtató törekvéseivel (ld. erról Polónyi és Kozma, 2019) indokolt felsốoktatás-szúkités súlyos társadalmi következményekkel jár. A hazai közoktatás erốsen szelektív jellege különösen felerósiti azt a hatást, amely a létszámszúkités miatt egyébként is fenyeget: nevezetesen azt, hogy a felsôoktatásból kiszorulnak az alsóbb társadalmi rétegek.

\section{Irodalom}

Altbach, Ph. G., Reisberg, L. \& Rumble, L. E. (2009). Trends in Global Higher Education: Tracking an Academic Revolution. A Report Prepared for the UNESCO 2009 World Conference on Higher Education DOI: 10.1163/9789004406155

http://www.cep.edu.rs/public/Altbach,_Reisberg, Rumbley Tracking an Academic Revolution, UNESCO_2009.pdf Utolsó letöltés: 2019. 05. 05.

Fokozatváltás a felsőoktatásban. Középtávú szakpolitikai stratégia. 2016. EMMI, Budapest. http:// www.kormany.hu/download/c/9c/e0000/Fokozatvaltas_Felsooktatasban_HONLAPRA.PDF Utolsó letöltés: 2020. 06. 10.

Polónyi István \& Kozma Tamás (2019). Az egyetemfejlesztés alternatívái. Magyar Tudomány, 9. 13261336. DOI: 10.1556/2065.180.2019.9.9

Polónyi István (2012). Honnan jönnek a hallgatók? Educatio, 2. 244-258.
Polónyi István (2018). A hátrányos helyzetü kistérségekben élő fiatalok felsőoktatásba kerülésének esélyei. Statisztikai Szemle, 10. 1001-1019. DOI: 10.20311/ stat2018.10.hu1001

Polónyi István (2019). Egyetemek és régiójuk - különös tekintettel a Debreceni Egyetemre. Debreceni Szemle, 1. 23-34.

Polónyi István (2020). A felsőoktatás politikai gazdaságtana. Budapest: Gondolat.

Széll Kálmán Terv. Összefogás az adósság ellen. (2010) https://2010-2014.kormany.hu/download/4/d1/20000/ Sz\%C3\%A911\%20K\%C3\%A11m\%C3\%A1n\%20Terv. pdf Utolsó letöltés: 2020. 06. 10.

A következö lépés. Széll Kálmán Terv 2.0. (2012) https://2010-2014.kormany.hu/download/3/e8/ $80000 / 1$ - A k k C $3 \%$ B 6 v e t k e z \% C $5 \%$ 91_1\%C3\%A9p\%C3\%A9s\%20\%28SzKT\%2020\%29. pdf Utolsó letöltés: 2020. 06. 10. 


\section{Melléklet}

Melléklet 1. táblázat. A jelentkezök és felvettek létszámának alakulása

\begin{tabular}{|l|c|c|c|c|}
\hline $\begin{array}{c}\text { A szeptemberben } \\
\text { induló képzésekre } \\
\text { irányuló felvételiken }\end{array}$ & $\begin{array}{c}\text { Összes } \\
\text { jelentkező }\end{array}$ & $\begin{array}{c}\text { Az adott évben 19 és } \\
\mathbf{1 8} \text { vagy kevesebb éves } \\
\text { jelentkező együtt }\end{array}$ & $\begin{array}{c}\text { Összes } \\
\text { felvett }\end{array}$ & $\begin{array}{c}\text { Az adott évben 19 } \\
\text { és 18 vagy kevesebb } \\
\text { éves felvett együtt }\end{array}$ \\
\hline 2006 & 132771 & 58404 & 94142 & 42211 \\
\hline 2007 & 108928 & 53365 & 81637 & 40320 \\
\hline 2008 & 96991 & 44758 & 81108 & 38448 \\
\hline 2009 & 127306 & 50826 & 94724 & 37996 \\
\hline 2010 & 140308 & 50704 & 98246 & 36688 \\
\hline 2011 & 140954 & 48307 & 98144 & 34882 \\
\hline 2012 & 110616 & 41161 & 80136 & 31264 \\
\hline 2013 & 95447 & 36031 & 72679 & 29425 \\
\hline 2014 & 106175 & 37288 & 74182 & 27135 \\
\hline 2015 & 105646 & 36606 & 72260 & 25688 \\
\hline 2016 & 111219 & 36312 & 74901 & 25794 \\
\hline 2017 & 105868 & 34388 & 72758 & 25429 \\
\hline 2018 & 107700 & 35785 & 75291 & 26483 \\
\hline 2019 & 112033 & 39252 & 78980 & 29053 \\
\hline 2020 & 91460 & 32083 & 68112 & 26961 \\
\hline
\end{tabular}

Forrás: felvi.hu

Melléklet 2. táblázat. Az alap és osztatlan képzésre összesen és a részidös képzésre jelentkezök és felvettek száma

\begin{tabular}{|l|c|c|c|c|c|c|}
\hline & $\begin{array}{c}\text { AO } \\
\text { jelentkező }\end{array}$ & $\begin{array}{c}\text { AO } \\
\text { felvett }\end{array}$ & $\begin{array}{c}\text { AON } \\
\text { jelentkezo }\end{array}$ & $\begin{array}{c}\text { AON } \\
\text { felvett }\end{array}$ & $\begin{array}{c}\text { AOR } \\
\text { jelentkező }\end{array}$ & $\begin{array}{c}\text { AOR } \\
\text { felvett }\end{array}$ \\
\hline 2006 & 112974 & 77979 & 83906 & 52885 & 29068 & 25094 \\
\hline 2007 & 96037 & 70030 & 76392 & 50405 & 19645 & 19625 \\
\hline 2008 & 85901 & 68897 & 65240 & 48567 & 20661 & 20330 \\
\hline 2009 & 103415 & 71259 & 80672 & 50370 & 22743 & 20889 \\
\hline 2010 & 107690 & 69948 & 84596 & 50697 & 23094 & 19251 \\
\hline 2011 & 106098 & 71253 & 84360 & 51571 & 21738 & 19682 \\
\hline 2012 & 81236 & 59784 & 67743 & 47556 & 13493 & 12228 \\
\hline 2013 & 72914 & 55053 & 60268 & 44196 & 12646 & 10857 \\
\hline 2014 & 79256 & 53648 & 63975 & 41689 & 15281 & 11959 \\
\hline 2015 & 78607 & 51670 & 64120 & 40145 & 14487 & 11525 \\
\hline 2016 & 83271 & 53999 & 65727 & 41021 & 17544 & 12978 \\
\hline 2017 & 82703 & 55225 & 63624 & 41318 & 19079 & 13907 \\
\hline 2018 & 84291 & 57068 & 64708 & 42320 & 19583 & 14748 \\
\hline 2019 & 88839 & 61041 & 68459 & 44989 & 20380 & 16052 \\
\hline 2020 & 69281 & 49640 & 56691 & 39741 & 12590 & 9899 \\
\hline
\end{tabular}

Forrás: felvi.hu 
Melléklet 3. táblázat. Korreláció a jelentkezők számának változása és a 2018-ban felvettek emelt szintú érettségi aránya, valamint a felvettek számának változása és a 2018-ban felvettek emelt szintü érettségi aránya között

\begin{tabular}{|c|c|c|c|c|}
\hline & $\begin{array}{c}\text { Jelentkezők } \\
\text { számának } \\
\text { változása } \\
\text { 2020-ban } \\
\text { 2019-hez } \\
\text { képest (\%) }\end{array}$ & $\begin{array}{c}\text { A 2018-ban } \\
\text { felvettek között } \\
\text { emelt szintű } \\
\text { érettségiért } \\
\text { többletpontot } \\
\text { kapottak aránya }\end{array}$ & $\begin{array}{c}\text { Felvettek } \\
\text { számának } \\
\text { változása } 2020 \text { - } \\
\text { ban } 2019-h e z \\
\text { képest }(\%)\end{array}$ & $\begin{array}{c}\text { A 2018-ban } \\
\text { felvettek között } \\
\text { emelt szintü } \\
\text { érettségiért } \\
\text { többletpontot } \\
\text { kapottak aránya }\end{array}$ \\
\hline agrár & $-25 \%$ & $27 \%$ & $-23 \%$ & $27 \%$ \\
\hline államtudományi & $-11 \%$ & $92 \%$ & $3 \%$ & $92 \%$ \\
\hline $\begin{array}{l}\text { bölcsésze- } \\
\text { ttudomány }\end{array}$ & $2 \%$ & $48 \%$ & $4 \%$ & $48 \%$ \\
\hline $\begin{array}{l}\text { gazdaság- } \\
\text { tudományok }\end{array}$ & $-16 \%$ & $41 \%$ & $-13 \%$ & $41 \%$ \\
\hline informatika & $-20 \%$ & $22 \%$ & $-14 \%$ & $22 \%$ \\
\hline jogi & $1 \%$ & $50 \%$ & $-2 \%$ & $50 \%$ \\
\hline müszaki & $-34 \%$ & $37 \%$ & $-34 \%$ & $37 \%$ \\
\hline müvészet & $-6 \%$ & & $8 \%$ & \\
\hline $\begin{array}{l}\text { müvészet- } \\
\text { közvetítés }\end{array}$ & $7 \%$ & & $-8 \%$ & \\
\hline $\begin{array}{l}\text { orvos- és egész- } \\
\text { ségtudomány }\end{array}$ & $-16 \%$ & $45 \%$ & $-7 \%$ & $45 \%$ \\
\hline pedagógusképzés & $-40 \%$ & $18 \%$ & $-29 \%$ & $18 \%$ \\
\hline sporttudomány & $-24 \%$ & $34 \%$ & $-8 \%$ & $34 \%$ \\
\hline $\begin{array}{l}\text { társadalom- } \\
\text { tudomány }\end{array}$ & $-5 \%$ & $93 \%$ & $5 \%$ & $93 \%$ \\
\hline $\begin{array}{l}\text { természet- } \\
\text { tudomány }\end{array}$ & $-11 \%$ & $68 \%$ & $-10 \%$ & $68 \%$ \\
\hline Korreláció & \multicolumn{2}{|c|}{0,6157} & \multicolumn{2}{|c|}{0,7061} \\
\hline
\end{tabular}


${ }^{1}$ A jogi alapképzésre jelentkezők esetében is nagyon alacsony volt az emelt szintü érettségivel rendelkezők aránya, azonban az ő jelentkezési és felvett arányuk nem látszik a táblán, mert az osztatlan képzéssel együtt szerepelnek. Ráadásul az osztatlan jogászképzés esetében lecsökkentett államilag finanszírozott ponthatár megnövelte a jelentkezők és a felvettek számát is.

2 A törvény szerint az államilag támogatott képzés költségeinek többségét a törvényben meghatározottak szerint az állami költségvetés, a költségtérítéses képzés költségeit a hallgató viseli. Az államilag támogatott alap- és mesterképzésben tanulmányokat folytató hallgató képzési hozzájárulás fizetésére köteles.

3 Ezt a szakirodalom „kétlépcsős tandíjnak” nevezi, ilyen van számos átmeneti gazdaságban, mint például Magyarországon, Oroszországban, Kelet- és Közép-Európában (ld. pl. Altbach és mtsai, 2009).

4 A,részben” azt jelenti, hogy 2013 után - mint arról lesz szó - az államilag támogatott felvételi keretszámokat, ha nem is radikálisan, de jelentősen szükítette, s a korábban a képzési normatívával nagyjából azonos költségtérítést ún. önköltségi szintre emelte, és a diákhitel 2-t valóban bevezette.

5 A Fokozatváltás a felsőoktatásban címü (Fokozatváltás 2016) anyag, amelyet a kormány 2016-ban hagyott jóvá, arra a kérdésre, hogy „Milyen felsőoktatást képzelünk el tehát 2030-ban?”, azt írja: „Minden [magyar felsőoktatási] intézmény világszínvonalú [kell legyen] azokban a diszciplínákban, amelyek a saját kiemelt területéhez tartoznak, összességében pedig az ország felsőoktatási intézményei kollektíven minden tudásterületet és tudásszintet lefednek.” (Fokozatváltás 2016. 13.)

${ }^{6}$ A Széll Kálmán Terv a kormányprogramot idézve írja: „Jelenleg a felsőoktatásban szerezhető diplomák felére nincs piaci kereslet” (Széll Kálmán Terv, 2010. 23.). Vagy a Széll Kálmán Terv 2.0 „a felsőoktatás támogatásában a 2012-re érvényesített és a 2013-ra tervezett további szúkítésével párhuzamosan [...] az átgondolt és tervszerü döntések szükségességét, az állam szerepének újragondolását, adott kérdésekben erősítését fogalmazza meg. [...] A 2012/2013 tanévre a felvehető állami ösztöndíjas létszámkeretet a Kormány a 2011. évi 53450 föről 34087 före szükítette. [...] E döntés keretében egyúttal sor került a képzési szerkezet belső összetételének - a természettudományos és müszaki, informatikai képzések nagyobb arányát biztosító átalakítására is.” (Széll Kálmán Terv 2.0, 2012. 199.)

7 „A felsőoktatási törvény 46. § 4) A miniszter évente [...] határozattal állapítja meg azt, hogy mely, a felsőoktatási intézmények által folytatott szakos képzésen vehető igénybe magyar állami (rész)ösztöndíj. A képzésre a felvétel teljesítéséhez szükséges minimális felvételi követelményt (pontszámot) a Kormány rendelete, az adott szak magyar állami (rész)ösztöndíjjal támogatott képzésére történő éves felvétel feltételeként teljesítendő minimális felvételi követelményt (pontszámot) a miniszter határozata állapítja meg. A határozatot a miniszter által vezetett minisztérium hivatalos lapjában közzé kell tenni."

${ }^{8}$ Az alapszakok: alkalmazott közgazdaságtan, andragógia, emberi erőforrások, gazdálkodási és menedzsment, igazságügyi igazgatási, kereskedelem és marketing, kommunikáció- és médiatudomány, közszolgálati, munkaügyi és társadalombiztosítási igazgatási, nemzetközi gazdálkodás, nemzetközi tanulmányok, pénzügy és számvitel, turizmus-vendéglátás, üzleti szakoktató - az osztatlan képzési szakok: gazdaság- és pénzügy-matematikai elemzés, valamint a jogász.

${ }^{9}$ OECD.Stat adat. (https://data.oecd.org/eduatt/population-with-tertiary-education.htm) 